\title{
Restricting minor surgery in general practice: another example of financial short-termism
}

Minor surgery has been a feature of general practice for many years. The 1990 general practice contract offered, for the first time, financial remuneration for its provision, although the number of claims that could be made was capped. ${ }^{1}$ Under the current GMS2 contract, minor surgery is remunerated as an Enhanced Service, with a fee per unit of clinical activity. ${ }^{2}$ Recently, however, many PCTs, including my own in Hertfordshire, have expressed concern that too many inappropriate excisions were taking place, increasing payments to GPs, such that we are now required to submit a request for approval (or otherwise) prior to undertaking excision surgery. In this essay I shall argue that this is yet another bureaucratic hurdle which, although it may reduce payments to GP colleagues in the short term, is likely to increase overall costs as well as making the patient pathway unnecessarily complicated. I shall use my own data to illustrate these points.

As a service, minor surgery in general practice is appreciated by patients and is cost-effective for the health economy. ${ }^{3}$ It is also satisfying for GPs, providing a chance to heal patients directly with our hands rather than the usual armamentarium of advice or drugs. With proper training and sensible procedural adherence, including wound care, it is safe and eases the burden on secondary care, particularly on those who work in dermatology and plastic surgery, who can concentrate their expertise on complex cases. Concerns have been expressed by PCTs that some colleagues have been submitting specimens such as minute skin tags for histological analysis inappropriately, and if the financial incentive to do so has led some to such sharp practice, I trust the majority of us would repudiate this. However, wider professional opinion varies between doctors who advocate that all excised specimens be submitted for histological analysis ${ }^{4}$ and those adopting a more conservative approach. ${ }^{5}$ Furthermore, if the surgery that would previously have taken place in primary care eventually gravitates to secondary care, it is unlikely that the proportion of specimens sent for analysis would vary appreciably. ${ }^{3}$

My data suggest that judicious use of histopathology is essential. I am one of four partners at Chorleywood Health Centre, a practice with a list size of 6200 ; so our surgical activity is probably fairly representative of an average practice. During the last financial year (2008/9), a total of 47 excisions, 13 incisions, and two aspirations were performed. Of the 47 excised specimens, 46 were sent for histological analysis and 44 reports were obtained. These comprised the following:

- Seborrhoeic keratosis, $n=14$

- Sebaceous cyst, $n=8$

- Fibroepithelial polyp, $n=5$

- Benign naevus, $n=5$

- Dermatofibroma, $n=2$

- Haemangioma, $n=2$

- Viral wart, $n=1$

- Chronic inflammation, $n=1$

- Solar keratosis, $n=1$

- Basal cell carcinoma, $n=2$

- Squamous cell carcinoma, $n=1$.

Three of the seborrhoeic keratoses were reported as dysplastic, as was the solar keratosis (that is, four potentially pre-malignant lesions). More importantly, despite generally sound clinicopathological correlation, a year of surgical activity yielded three unexpected malignant tumours. These were:

1. A patient with a small area of basal cell carcinoma change at the tip of a wart which was fully excised. The patient was written to and happy to leave matters.

2. Another patient with a basal cell tumour had her problem discussed and a referral offered, but as the excision margins were comfortably clear she declined this.

3. The patient with the squamous carcinoma was referred to plastic surgery for a wider excision and has done well.

The complication rate was low. One patient, who had significant medical problems and a large, multifocal abscess, required a second incision and prolonged treatment of the wound. Another older patient who had an axillary sebaceous cyst removed developed a wound infection and required antibiotics. Only two patients required referral, in both cases to plastic surgery. These were the aforementioned man with the squamous tumour, as well as a young man with a recurrent cyst on his ear.

Taking as broad a view as reasonably possible, it is highly improbable that current PCT strategy to restrict minor surgery in general practice has much worth, in any sense of the word. Taking finances first, my practice's gross earnings from the year's activity, based on current tariffs, was £4687: when equipment and other expenses are factored in, it is unlikely that the real (pretax) profit would exceed $£ 3000$. As a proportion of the total health economy, this is trivial: any savings achieved by restricting minor surgery would be small, and swiftly negated by the wages paid to the PCT managers and consultants who now police this. The latter are entrusted with making value-laden judgements: in practice, which fibroepithelial polyp is worthy of excision and which is not. Highly personal matters come into play: you and I may be sanguine about blemishes that would be wholly unacceptable to an aspiring young fashion model who has yet to acquire the personal wealth to afford private 
treatment. Successive governments over the last three decades have gleefully espoused commercial values, and Thatcher's children will not learn to accept 'no' in their middle age. What is diverted from primary care will gravitate to hospitals, and be treated at much higher cost. It is ironic that while PCTs pinch pennies from general practice, acute hospital trusts can still expect to have gargantuan budget overspends written off centrally - a case of general practice being a victim of its good housekeeping and transparency.

Sadly, minor surgery is not an isolated case, merely one of many examples of fiscal and service planning mismanagement. At a time of national financial crisis, the government has nonetheless seen fit to spend £8 million of taxpayers' money (how much healthcare could that purchase?) on the Patient Access Survey, a self-indulgent and vainglorious act rightly derided by GPC Chairman Laurence Buckman as a mere ploy to deprive practices of income. ${ }^{6}$ At the same time, the axe is constantly falling on what should constitute core services. Forgive me for again citing my practice's experience, but it is instructive. In the last few years my partners and I have coped with the loss of an Integrated Nursing Team as retirees were not replaced, the removal of health visiting from the surgery to a clinic a couple of miles away (not always easy to reach in a semi-rural community where all journeys apart from the rail commute to London require a car), and seen counselling and physiotherapy under constant threat. A clear pattern is emerging, for behind the sugary rhetoric of a 'primary care-led NHS' and 'patient choice' lies a very different reality, one of laceration of services to such an extent that we risk regressing to a 1970 s model of a basic consulting and home visiting service.

If anything should unite healthcare professionals and the wider public it is that, should this occur, we will all suffer. In the last two decades general practice has had an excellent track record in taking on chronic disease management from the hospital setting, obvious examples being asthma, hypertension and diabetes. If this is not built upon or, worse still, the trend becomes reversed, the deleterious effects on primary care are obvious. However, hospitals will also suffer, with a sharp rise in workload and waiting times, for they cannot sustain all they presently do and also absorb more elective work from the community. Overall costs will also rise, for a basic tenet in health economics is that secondary care is much more expensive. The public will be hit by a double blow of impoverished primary care provision while being asked to pay yet more tax already punitive for middle-income earners $^{7}-$ to fund hospital services.

Current NHS policy demeans general practice by overvaluing superficial targets such as access, while stifling innovation and service development that could make a telling impact on the patient experience, something which I am certain is widely recognised among patients. Granted, there is no flawless way to fund a health service, and globally all societies wrestle with the vagaries of their systems; however, we can surely do better than our current fragmented and bureaucratic model. Fundholding, imperfect and divisive as it was ${ }^{8}$ supported massive expansion of services within primary care for those practices willing and able to grasp the opportunity, and it handed governance to the people to whom it should belong - clinicians. ${ }^{9}$ Experience over the past two decades suggests that a return to devolved budgets may not be just a possibility for primary care, but it's sole saviour.

\section{Edin Lakasing}

\section{REFERENCES}

1. Department of Health and the Welsh Office. General Practice in the National Health Service. A new contract. London: HMSO, 1989.

2. Department of Health. Investing in general practice: the new general medical services contract. London, DoH, 2003.

3. O'Cathain A, Brazier JE, Milner PC, Fall M. Cost effectiveness of minor surgery in general practice: a prospective comparison with hospital practice. $\mathrm{Br}$ Gen Pract 1992; 42: 13-17.

4. Jacob A, Jacyna MR. Minor surgery in general practice (letter). J R Coll Gen Pract 1986; 36: 292.

5. Paraskevolpoulos JA, Hosking JW, Johnson AG. Do all minor excised lesions require histological examination? J R Soc Med 1988; 81: 583-584.

6. Management in Practice. 'Flawed and unfair' patient access survey will hit practices, BMA warns. 1 June 2009.

http://www.managementinpractice.com/default.asp?p age $=$ article display\&title $=\% 22$ Flawedandunfair $\% 22 p$ atientaccesssurveywillhitpractices\%2CBMAwarns\&ar ticle.id=16857 (accessed 8 Apr 2010).

7. Lakasing E. Health inequalities in the UK: remedy requires action beyond redistribution of wealth. $\mathrm{Br} J$ Gen Pract 2009; 59: 782-784.

8. Neal J. Practice based commissioning: an introduction. BMJ 2005; 331: 130-131.

9. Howie JGR, Heaney DJ, Maxwell M. General practice fundholding: Shadow project - an evaluation. Edinburgh: University of Edinburgh Press, 1995.

DOI: 10.3399/bjgp10X502029 